Original Research Paper

\title{
Cadmium (Cd) Resistance of Isolate Bacteria from Poboya Gold Mining in Palu, Central Sulawesi
}

\author{
Fahruddin $^{1 *}$, Syahruddin Kasim ${ }^{2}$, Eka Ummi Rahayu ${ }^{1}$ \\ ${ }^{1}$ Departemen Biologi, Fakultas Matematika dan Ilmu Pengetahuan Alam, Universitas Hasanuddin, Makassar, Indonesia; \\ ${ }^{2}$ Departemen Kimia, Fakultas Matematika dan Ilmu Pengetahuan Alam, Universitas Hasanuddin, Makassar, Indonesia
}

\author{
Article History \\ Received : August $05^{\text {th }}, 2020$ \\ Revised : August $12^{\text {th }}, 2020$ \\ Accepted : August $15^{\text {th }}, 2020$ \\ Published : August $16^{\text {th }}, 2020$ \\ *Corresponding Author: \\ Fahruddin, \\ Departemen Biologi, Fakultas \\ Matematika dan Ilmu \\ Pengetahuan Alam, Universitas \\ Hasanuddin, Makassar, \\ Indonesia; \\ Email: \\ fahruddin_science@unhas.ac.id
}

\begin{abstract}
The mining industry in Indonesia is growing rapidly, giving an environmental impact from the waste produced because it contains dangerous heavy metals, one of which is cadmium metal $(\mathrm{Cd})$. The purpose to know the ability of cadmium resistance in bacterial isolates. Bacterial isolates were obtained from soil samples from the Poboya Gold Mine field, Palu. Bacterial isolation and selection were carried out by the plate count method, resistance testing using nutrient broth media containing heavy metals $\mathrm{Cd}$, analysis of $\mathrm{Cd}$ concentrations using atomic absorption spectrophotometers. From the results of the study, four types of $\mathrm{Cd}$ resistant isolates were obtained based on macroscopic and microscopic characterization results, namely isolates EK1, EK2, EK3 and EK4. The two best isolates of Cd resistance, EK2 and EK4 isolates were tested on media containing $20 \mathrm{ppm} \mathrm{Cd}$, showing that both of these isolates were able to significantly reduce $\mathrm{Cd}$ concentrations in the supernatant and pellets.
\end{abstract}

Keywords: resistance; bacterial colonies; cadmium; resistant bacteria

\section{Pendahuluan}

Kemajuan industri pertambangan di Indonesia memiliki dampak positif yaitu peningkatan ekonomi, kesejahteraan rakyat dan penyerapan tenaga kerja, namun demikian kemajuan pertambangan juga memberikan konsekuensi oleh adannya berbagai jenis limbah yang dihasilkan, berakibat pada pencemaran lingkungan (Widyati, 2007; Fahruddin et al. 2018). Hal ini berkontribusi besar bagi kerusakan lingkungan karena limbah pertambangan dibuang tidak terkontrol, dan masuk ke sungai, hutan, estuari dan wilayah pantai. Hal ini menimbulkan pengendapan sedimen, kandungan limbah logam berbahaya (Gaikwad et al., 2011; Rinasari et al., 2019).

Kegiatan pertambangan memberikan dampak pada lingkungan, karena batuan yang digali atau diangkat dari bawah tanah mengandung logam sulfit atau dikenal sebagai metal sulfit, bila terekspos dengan udara akan menghasilkan sulfat $\left(\mathrm{SO}_{4}\right)$. Selanjutnya jika terkena air atau ada air hujan akan membentuk asam sulfat $\left(\mathrm{H}_{2} \mathrm{SO}_{4}\right)$. Senyawa sulfat yang terbentuk ini akan menjadi sumber pencemaran terutama pada badan sungai. Biota air akan terganggu kehidupannya oleh adanya sifat asam pada air dengan nilai $\mathrm{pH}$ 2-3.

Di lain pihak asam sulfat tersebut akan menyebabkan logam - logam berat yang tedapat pada bijih tambang menjadi larut dan juga terbawa air. Jika logam berat ini masuk ke perairan akan menjadi racun bagi berbagai oragnisme, karena sifat toksisitas pada logam itu. Akibat dari proses ini menyebabkan limbah pertambangan menghasilkan dua jenis sumber pencemaran yaitu kandungan sulfat dan kandungan logam - logam berat yang berbahaya, limbah ini disebut air asam tambang (Widyati, 2007; Fahruddin et al., 2018). Selain itu, terdapat buangan lain dari kegiatan pertambangan, misalnya sisa bijih tambang, tailing, slugde dan buangan lainnya yang berupa limbah padat. Tentunya jika tidak dikontrol akan berdampak buruk bagi pekerja tambang, maupun bagi masyarakat yang bermukim di sekitar lahan pertambangan (Astiti \& Sugianti, 2014).

Kegiatan pertambangan yang makin berkembang di Indonesia adalah pertambangan bijih emas, bahkan ada kegiatan pertambangan emas yang tidak legal. Karena tidak terkontrol sehingga tidak disadari memberikan dampak pencemaran sisa buangan pertambangan tersebut yang berbahaya, karena masih mangandung logam berat lainnya yang memiliki sifat toksik yang tinggi. (Fahruddin et al., 2020). Salah satu logam berat yang banyak terkandung dalam buangan limbah pertambangan adalah logam berat kadmiun (Cd), terutama terdapat dalam tailing dan air asam tambang. Salah satu pertambangan di Indonesia adalah 
pertambangan emas Poboya terletak di Kecamatan Palu Timur, Kota Palu, Propinsi Sulawesi Tengah (Cyio et al., 2012), seperti terlihat pada Gambar 1. Dari hasil penelitian limbahnya mengandung sejumlah logam berat (Golar et al., 2019).

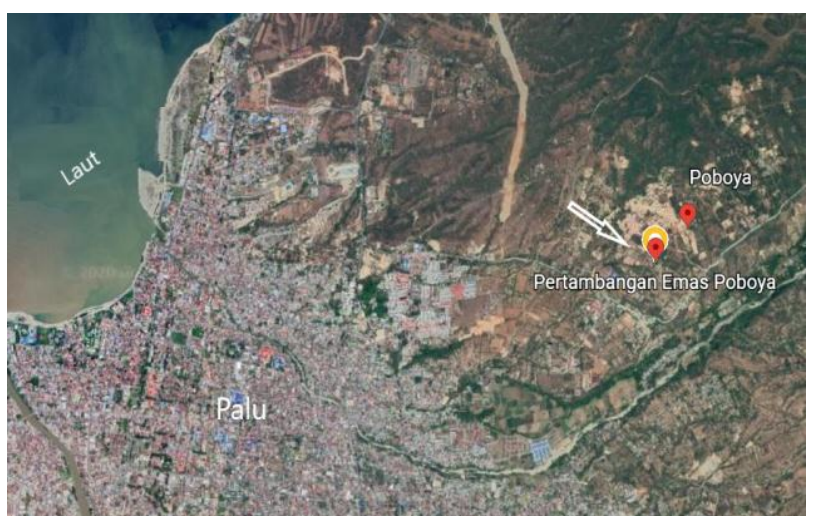

Gambar 1. Lokasi pertambangan emas Peboyo, Palu, Sulawesi Tengah

Pada lahan pertambangan emas Peboyo, masih terdapat sisa - sisa bijih tambang yang dihasilkan mengandung banyak logam berat, terutama logam berat kadmium (Wawo et al., 2017; Golar et al., 2019). Logam ini bersifat toksik, sehingga membahayakan pada kesehatan manusia, termasuk pada organisme yang lain (Cyio et al., 2017). Dapat menimbulkan efek khusus pada mahkluk hidup bila masuk dalam tubuh (Palar, 2004).

Secara alami di lingkungan, logam berat seperti kadmium mengalami tahapan transformasi dan akumulasi dalam jaringan mahluk hidup, yaitu pada hewan, tumbuhan dan termasuk pada manusia. Transformasi ini terjadi melalui rantai makanan dengan cara logam berat kadmium masuk ke dalam tubuh bersama makanan (Nur, 2013; Fahruddin \& Asadi, 2018). Logam berat bertransformasi melalui mekanisme bioakumulasi di dalam jaringan tubuh organisme hidup. Jadi sepanjang kehidupan organisme tersebut jumlah logam berat yang terakumulasi akan terus terjadi peningkatan. Di samping itu, faktor yang menentukan adalah tingkat trofik biota dalam sistem rantai makanan yang berperan dalam menentukan kadar logam Cd yang terakumulasi. Bila jumlah kadar logam berat $\mathrm{Cd}$ yang yang terakumulasi tersebut melebihi ambang batas, maka organisme yang terkontaminasi logam berat $\mathrm{Cd}$ akan mengalami kematian (Barokah et al., 2019; Nurhayati \& Didha, 2019).

Teknologi yang dapat digunakan mereduksi pencemaran logam berat pada tanah yaitu dengan metode kimia, fisik, dan biologis, namun metode biologis, dianggap sebagai teknologi yang paling efektif dan ramah lingkungan dibandingkan dengan metode yang lain (Hasyimuddin et al., 2018).

Salah satu upaya penanganan pencemaran logam berat pada tanah adalah menggunakan mikroorganisme yaitu dengan bioremediasi. Bioremediasi mensyaratkan adanya agen biologis dalam proses pengembalian kondisi tanah tersebut dari akumulasi logam berat dalam tanah (Fahruddin, 2014). Bioremediasi diterapkan dengan mengandalkan kemampuan resistensi dari bakteri itu, didukung dengan penambahan nutrien untuk memicu pertumbuhan bakteri pada tanah yang terkontaminasi logam berat, bahkan dapat ditingkatkan kemampuanya dengan penambahan mikroba eksogen sebagai kultur bakteri campuran (Ahmad, 2018; Ikerismawati, 2019).

Bakteri resisten logam berat $\mathrm{Cd}$ untuk proses bioremediasi diperoleh dari lingkungan tercemar, termasuk pada lahan pertambangan emas, karena yang diisolasi dari lahan yang tercemar memiliki tingkat resistensi yang tinggi terhadap zat pencemar logam berat dan berpotensi dimanfaatkan untuk tujuan bioremediasi (Jamilah \& Amri, 2019).

Pendekatan secara mikrobiologis merupakan alternatif yang baik dan ramah lingkungan dapat dilakukan karena lebih ekonomis dan mudah dilakukan karena membutuhkan lahan yang tidak luas, sehingga metode mikrobiologi lebih prospek, yaitu dengan memanfaatkan bakteri dalam mereduksi logam berat yang terdapat dalam sisa buangan pertambangan (Gaikwad et al., 2011). Oleh karena itu maka perlu dilakukan isolasi dan uji resistensi bakteri terhadap logam berat $\mathrm{Cd}$.

\section{Bahan dan Metode}

\section{Waktu dan Tempat}

Penelitian ini dilaksanakan pada Februari - Juli 2020, di Laboratorium Mikrobiologi, Departemen Biologi, Fakutas Matematika dan Ilmu Pengetahuan Alam, Universitas Hasanuddin, Makassar.

\section{Sampel dan Media}

Sampel tanah diperoleh dari lahan tambang emas Poboya, Palu, Sulawesi Tengah, dimasukkan dalam wadah plastik setril. Media pertumbuhan bakteri yang digunakan adalah nutrient broth dengan komposisi: pepton $10 \mathrm{~g}$, $\mathrm{NaCl} 5$ g, ekstrak daging sapi 3 g dalam $1000 \mathrm{ml}$. Media Nutrien Agar dengan komposisi: 0,5\% pepton, 0,3\% ekstrak daging sapi, 1,5\% agar, $0,5 \% \mathrm{NaCl}$.

\section{Analisis Logam Berat Kadmium}

Penentuan konsentrasi logam berat kadmium pada sampel tanah dilakukan dengan metode Spektrofotometer Serapan Atom (SSA), dengan berpatokan pada larutas baku standar sebagai dasar dalam kurva kalibrasi yaitu pada sumbu $x$ adalah konsentrasi sedangkan sumbu $y$ 
adalah absorabansi. Penetapan konsentrasi kadmium dengan mengambil $100 \mathrm{~mL}$ larutan sampel absorbansi diukur menggunakan pada panjang gelombang 228,8 nm. Berikutnya, hasil pengukuran absorbansi dari larutan standar kadmium diplotkan terhadap konsentrasi larutan kadmium pada sampel.

\section{Isolasi dan Seleksi Bakteri Resiten Kadmium}

Sampel tanah dilakukan pengenceran secara berseri dengan mengambil menimbang $1 \mathrm{mg}$ ke dalam $9 \mathrm{~mL}$ aquades steril, kemudian dihomogenkan sehingga didapatkan pengenceran, selanjutnya diinokulasikan pada media Nutrien Agar yang mengandung 5 ppm logam barat kadmium dan diinkubasi pada suhu $37^{\circ} \mathrm{C}$ selama 2 × 24 jam. Selanjutnya mengamati koloni yang tumbuh dan memisahkan koloni yang berbeda pada agar miring dalam tabung reaksi.

\section{Karakterisasi Isolat Bakteri}

Pemeriksaan makroskopis koloni dinilai berdasarkan warna pertumbuhan koloni, bentuk elevasi, karakterisasi optis, dan permukaan koloni. Pengamatan secara mikroskopis yang dengan melakukan pewarnaan Gram, selanjutnya diamati dibawa mikroskop.

\section{Uji Resistensi Kadmium pada Isolat}

Isolat yang diperoleh dari hasil seleksi resisten kadmium, selanjutnya diinokulasikan ke dalam media nutrient broth yang mengandung kadmium dengan variasi konsentrasi 0 ppm, 5 ppm, 10 ppm, 15 ppm, dan 20 ppm. Setelah itu, diinkubasi pada suhu $37^{\circ} \mathrm{C}$ selama 48 jam. Setiap perlakuan pertumbuhan bakteri nilai OD (Optical Density) diukur pada spektrofotometer menggunakan panjang gelombang $580 \mathrm{~nm}$. Hasil absorban merupakan indikator untuk kepadatan populasi bakteri yang tumbuh. Isolat yang resisten terhadap logam berat kadmium berdasarkan tingkat kepadatan.

\section{Analisis Konsentrasi Akhir Kadmium}

Analisis konsentrasi akhir kadmium dengan menggunakan Spektrofotometer Serapan Atom (SSA), dilakukan pada nutrient broth yang berisi logam berat $\mathrm{Cd}$ $20 \mathrm{ppm}$, dan telah diinokulasikan isolat bakteri yang terbaik dalam resistensi logam $\mathrm{Cd}$. Analisis akhir konsentrasi logam Cd dilakukan pada supernatan dan pelet media.

\section{Hasil dan Pembahasan}

\section{Isolasi dan Seleksi Bakteri Resisten Kadmium (Cd)}

Dari hasil isolasi bakteri resisten kadmium menggunakan media nutrient broth yang ditambah 5 ppm, diperoleh 4 jenis koloni bakteri resisten dari pengamatan koloni yang tumbuh pada Nutrient Agar yaitu isolat EK1,
EK2, EK3, dan EK4. Keempat isolat ini memperlihatkan ciri morfologi koloni yang berbeda, seperti pada Gambar 2.
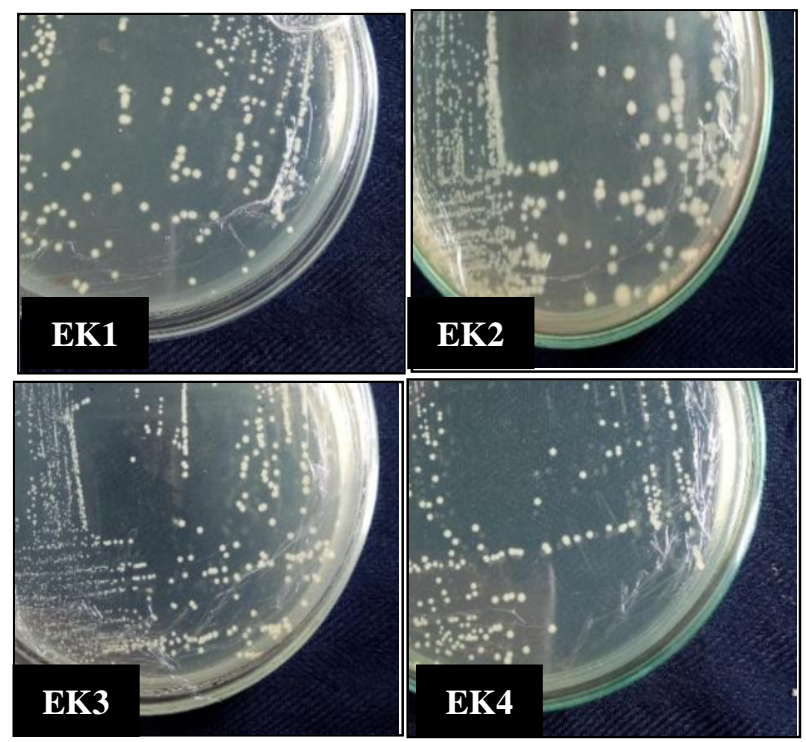

Gambar 2. Pertumbuhan koloni isolat bakteri EK1, EK2, EK3 dan EK4

Hasil pengamatan morfologi koloni bakteri menunujukkan bahwa warna koloni berwarna putih, kecuali pada isolat EK2 berwarna putih kekuningan. Bentuk koloni isolat juga memperlihatkan bentuk yang sama yaitu circular, kecuali yang berbeda adalah pada bentuk tepi yaitu entire, filamentous, dan undulate. Bentuk elevasi ada convex dan raised, seperti pada Tabel 1.

Tabel 1. Karakteristik morfologi koloni isolat bakteri

\begin{tabular}{|l|c|c|c|c|}
\hline \multirow{2}{*}{ Isolat } & \multicolumn{4}{|c|}{ Ciri Pertumbuhan Koloni } \\
\cline { 2 - 5 } & Warna & Bentuk & Tepi & Elevasi \\
\hline EK 1 & Putih & Circular & Entire & Convex \\
\hline EK 2 & $\begin{array}{c}\text { Kuning } \\
\text { kecoklatan }\end{array}$ & Circular & Filamentous & Raised \\
\hline EK 3 & Putih & Circular & Undulate & Convex \\
\hline EK 4 & Putih & Circular & Undulate & Convex \\
\hline
\end{tabular}

Karakteristik morfologi makroskopis ini merupakan pendekatan awal untuk mengidentifikasi bakteri akan membantu dalam identifikasi mikroorganisme. Koloni adalah massa mikroorganisme yang semuanya berasal dari sel induk tunggal. Oleh karena itu sebuah koloni merupakan mikroorganisme yang mirip secara genetis. Setiap jenis bakteri akan membentuk morfologi koloni yang berbeda. Warna koloni muncul karena sifat-sifat beberapa media atau karena produksi pigmen oleh bakteri. Beberapa bakteri menghasilkan koloni berwarna karena perubahan $\mathrm{pH}$ atau aktivitas enzimatik. Pigmen yang diproduksi oleh bakteri 
tertentu juga dapat mewarnai koloni. Setiap koloni yang berbeda mewakili klon bakteri individu (Fahruddin et al., 2019).

Pada pengecatan Gram, semua isolat berbentuk batang atau basil dengan sifat Gram positif seperti pada Tabel 2, bakteri bentuk basil dapat ditemukan di dalam tanah dan udara karena memiliki flagella yang digunakan oleh bakteri untuk menghindar pada lingkungan yang tidak kondusif bagi pertumbuhannya, atau sebaliknya flagella ini digunakan sebagai alat gerak menuju pada lingkungan yang menguntungkan untuk berkembang (Dwiyana \& Fahruddin, 2012).

Tabel 2. Pengecatan Gram pada isolat bakteri

\begin{tabular}{|c|c|c|}
\hline Isolat & Bentuk & Gram \\
\hline EK 1 & Basil & Positif \\
\hline EK 2 & Basil & Positif \\
\hline EK 3 & Basil & Positif \\
\hline EK 4 & Basil & Positif \\
\hline EK 1 & Basil & Positif \\
\hline
\end{tabular}

Uji resistesi pada isolat bakteri dilakukan adalah untuk mengkaji kapasitas sifat resistensi isolat bakteri pada logam berat kadmium, dengan perlakuan beberapa variasi kosentrasi kadmium yaitu 5 ppm, 10 ppm, 15 ppm, dan 20 ppm, serta kontrol tanpa adanya penambahan $\mathrm{Cd}$ pada media uji. Uji resistensi dilakukan pada 4 isolat, yaitu EK1, EK2, EK3 dan EK4. Dari uji resistensi tersebut memperlihatkan keempat isolat bakteri berbeda nilai OD yang ditunjuk pada spektrofotometer, seperti terlihat pada Gambar 3.

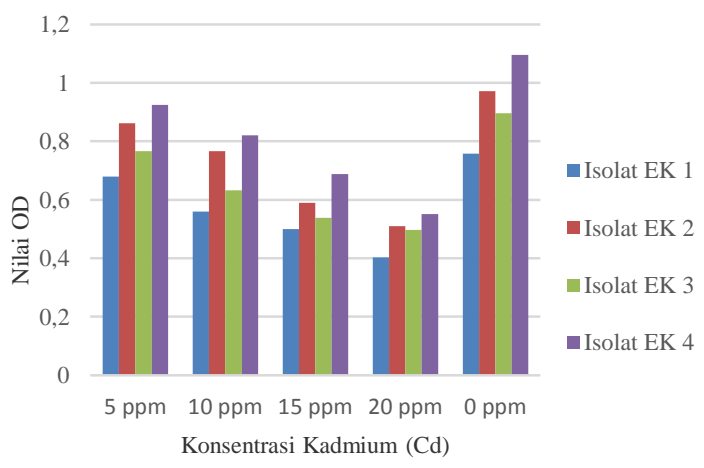

Gambar 3. Nilai OD pertumbuhan isolat bakteri pada media nutrient broth dengan variasi konsentrasi kadmium.

Hal ini bukti bahwa nilai OD yang berbeda sebagai petunjuk kepadatan populasi bakteri yang tumbuh berbeda pula. Secara keseluruhan berdasarkan pada pertumbuhannya, memperlihatkan isolat EK 4 memiliki tingkat resistensi yang paling tinggi dibandingkan dengan ketiga isolat yang lain. Pada isolat EK2 dan isolat EK4 menunjukkan kemampuan tumbuh lebih resisten dibandingkan dengan isolat EK1 dan EK3. Hal ini sebagai bukti bahwa isolat EK2 dan EK4 dapat bertahan pada logam Cd dengan konsentrasi tinggi dan dapat beradaptasi dengan memiliki fase pertumbuhan yang cukup lama.

Menurut Elliott, et al. (1998), bahwa semakin rendah nilai OD relevan dengan konsentrasi $\mathrm{Cd}$ yang ditambahkan pada media pertumbuhan. Pertumbuhan bakteri akan terhambat oleh adanya logam yang bersifat toksik pada metabolisme, sehingga dapat menghambat pertumbuhan bakteri, atau bahkan mematikan bakteri kerena logam menjadi inhibitor pada mekanisme enzimatik dalam sel mikroba.

\section{Konsentrasi Akhir Kadmium}

Isolat yang dipilih untuk uji resistensi selanjutnya adalah isolat terbaik dalam mereduksi logam berat $\mathrm{Cd}$ yaitu isolat EK2 dan isolat EK4. Dipilih berdasarkan kemampuan kedua isolat tersebut tumbuh pada konsentrasi logam berat $\mathrm{Cd}$ yang tinggi yaitu pada konsentrasi 20 ppm. Selanjutnya, diuji ulang kemampuan resistensinya pada larutan media yang mengadung 20 ppm logam berat $\mathrm{Cd}$. Hasilnya, kedua isolat ini mampu mereduksi jumlah logam berat $\mathrm{Cd}$ pada supernatan dan pada pelet. Pada isolat EK2 mampu menurunkan konsentarasi logam berat Cd dari 20 ppm yaitu sebesar $0,0853 \mathrm{ppm}$ berada pada supernatan dan 0,0631 ppm berada pada pelet, kemudian isolat bakteri EK4 mampu menurunkan konsentrasi logam berat kadmium sebesar 0,0813 ppm berada pada supernatan dan 0,0718 ppm berada pada pelet, seperti tercantum pada Tabel 3 .

Tabel 3. Konsentrasi akhir logam kadmium pada media Nutrient Broth yang mengandung konsentrasi logam Cd $20 \mathrm{ppm}$

\begin{tabular}{|l|l|c|}
\hline Isolat & $\begin{array}{c}\text { Keberadaan } \\
\text { Logam berat } \\
\mathrm{Cd}\end{array}$ & $\begin{array}{c}\text { Konsentrasi akhir } \\
\text { logam berat Cd } \\
(\mathrm{ppm})\end{array}$ \\
\hline EK2 & Supernatan & 0,0853 \\
\cline { 2 - 3 } & Pelet & 0,0631 \\
\hline EK4 & Supernatan & 0,0813 \\
\cline { 2 - 3 } & Pelet & 0,0718 \\
\hline
\end{tabular}

Mikroba yang mampu bertahan hidup dan berkembang pada media dengan konsentrasi logam berat $\geq 5$ ppm adalah dikategorikan bakteri yang mempunyai sifat resistensi tinggi terhadap logam berat. Kemampuan resistensi bakteri karena didukung oleh adanya gen yang dimiliki bakteri yang mengekspresikan produk metabolisme, seperti protein metallothionein atau produk metabolisme yang lain bersifat ekstraseluler seperti eksopolisakarida yang memiliki sifat ionik pada sejumlah 
logam berat (Dwiyana \& Fahruddin, 2012; Mu'minah et al., 2015).

Mekanisme lain yang terjadi pada bakteri dalam mereduksi logam berat ataupun sebagai cara dalam melindungi dari sifat logam berat yang bersifat toksik adalah dengan mekanisme biosorpsi. Mekanisme ini terjadi melalui interaksi logam dengan sejumlah molekul yang disekresikan oleh bakteri pada dinding selnya. Terjadi melalui proses kimiawi yaitu terjadi pengikatan logam secara kovalen, ikat ionik, ikat hidrogen dan ikatan kimia lainnya yang timbul dari asam - asam amino dan karbohidrat yang disekresikan dinding sel bakteri (Fahruddin et al., 2019).

Berdasarkan hasil di atas, yaitu isolate EK2 dan EK4 memiliki resistensi tinggi terhadap paparan Cd. Hal ini terjadi karena kelompok bakteri terdapat struktur senyawa lipoprotein, lipopolisakarida, fosfolipid, dan berbagai jenis kandungan protein yang ada pada dinding sel bakteri yang dapat digunakan melakukan proses detoksifikasi logam berat (Jin et al., 2018; Kapahi \& Sarita, 2019). Isolat bakteri EK2 dan EK4 yang diisolasi dari sampel tanah lahan pertambangan emas Peboyo, Palu Sulawesi Tengah, memiliki potensi dalam menyisihkan logam berat kadmium pada tanah tercemar logam berat Cd dengan teknik bioaugmentasi.

\section{Kesimpulan}

Dari hasil penelitian diperoleh empat jenis isolat bakteri yang memiliki resistensi pada logam berat kadmium (Cd) yaitu isolat EK1, EK2, EK3 dan EK4. Dari hasil uji pertumbuhan pada logam berat kadmium dengan konsentrasi 5 ppm, 10 ppm, 15 ppm, dan 20 ppm dipilih EK2 dan EK4 sebagai isolat terbaik. Selanjutnya, pada uji kemampuan resisten pada media yang mengandung logam berat $\mathrm{Cd} 20$ ppm menunjukkan kedua isolat mampu secara signifikan menurunkan konsentrasi kadmium yang berada pada supernatan dan pelet.

\section{Ucapan terima kasih}

Penulis berterimakasih kepada Ketua Departemen Biologi Fakultas MIPA, Universitas Hasanuddin atas fasilitasinya dalam penggunaan Laboratorium Mikrobiologi, demikian pula pada Kepala Laboratoriun atas dukungan sarana dan prasarana dalam mengerjakan penelitian ini.

\section{Referensi}

Ahmad, R.Z. (2018). Mikoremediasi Menghilangkan Polusi Logam Beratpada Lahan Bekas Tambang untuk Lahan Peternakan. Wartazoa, 28 (1):41-50. doi:

http://dx.doi.org/10.14334/wartazoa.v28i1.1785
Astiti, G. S. \& Sugianti, T. (2014). Dampak Penambangan Emas Tradisional Pada Lingkungan dan Pakan Ternak di Pulau Lombok. Sains Peternakan, 12(2): 101-106. $\quad$ https://jurnal.uns.ac.id/Sains Peternakan/article/view/4786/4128

Barokah, G.R., Dwiyitno \& Indrianto, N. (2019). Kontaminasi Logam Berat (HG, PB, dan CD) dan Batas Aman Konsumsi Kerang Hijau (Perna virdis) dari Perairan Teluk Jakarta di Musim Penghujan. Jurnal Pascapanen dan Bioteknologi Kelautan dan Perikanan, 14 (12): 95 95-104. doi: 10.15578/jpbkp.v14i2.611

Cyio, M.B., Uswah, H., Isrun, N. \& Yuka, S. (2012). Gold Mining Activities and Its Impacts on Land Degradation in Central Sulawesi Indonesia. Journal of Ecotechnology Research, 16 (4):7983.https://www.researchgate.net/publication/3238 81065_Gold_Mining_Activities_and_Its_Impacts on_Land_Degradation_in_Central_Sulawesi_In donesia.

Cyio, M.B., Mahfudz1., Takanobu, I., Alam, A., Tomori, K., Nurdin, R., Golar, Muhammad, R., Muhammad, N. A., Muhammad, R. R. \& Bohari. (2017). Impact of the Traditional Gold Mine Management on Public Health and Agricultural Land: A Study of Traditional Gold Mining in Poboya, Sausu and Dongi-Dongi Village, Central Sulawesi, Indonesia. Journal of Food, Agriculture \& Environment, $15 \quad$ (4):115-122. https://www.researchgate.net/publication/321314 364 Impact of the traditional gold mine mana gement on public health and agricultural land A Study of traditional_gold mining in Poboy a Sausu and DongiDongi_Village_Central Sulawesi_Indonesia.

Dwiyana, S. \& Fahruddin. (2012). Uji Resistensi Antibiotik pada Bakteri Resisten Merkuri ( $\mathrm{Hg}$ ) Yang di Isolasi dari Kawasan Pantai Losari Makassar, Sainsmat, 1 (2): 199-204. https://ojs.unm.ac.id/sainsmat/article/view/744.

Elliott, P., Ragusa, S. \& Catcheside, D. (1998). Growth of Sulfate-Reducing Bacteria Under Acidic Conditions In an Upflow Anaerobic Bioreactor As a Treatment System for Acid Mine Drainage. Water Research, 32(12):3724-3370. https://www.sciencedirect.com/science/article/abs /pii/S0043135498001444

Fahruddin \& Asadi, A. (2018). Analisis Populasi Bakteri pada Air Asam Tambang Dengan Perlakuan Sedimen Mangrove. Jurnal Ilmu Alam dan 
$\begin{array}{llll}\text { Lingkungan, } & 9 & (1): & 70-77 .\end{array}$

http://journal.unhas.ac.id/index.php/jai2/article/vi ew/4875.

Fahruddin, F. Nursiah L. \& Asadi, A. (2015). Use of Organic Materials Wetland to Improving the Capacity Sulfate Reduction Bacteria (SRB) of Reduce Sulfate In Acid Mine Water (AMW). Asian Journal of Microbiology Biotechnology \& Environmental Sciences, $17 \quad$ (2):321-324. http://www.envirobiotechjournals.com/article_abs tract.php?aid=5967\&iid=191\&jid=1

Fahruddin, F., As'adi, A. \& Nursiah, L. (2018). Treatment of Acid Mine Drainage Waste Using Sediment As Source of Sulfate-Reducing Bacteria to Reduce Sulfates. Pollution Research, 37 (4): 903-907. http://www.envirobiotechjournals.com/article_abs tract.php? aid $=9085 \&$ iid $=263 \&$ jid $=4$

Fahruddin, F., Eva, J. \& Zaraswati, D. (2019). Antifouling Potential of Thalassia Hemprichii Extract Against Growth of Biofilm-Forming Bacteria. ScienceAsia, (45): 21-27. http://www.scienceasia.org/2019.45.n1/scias45_2 $\underline{1 . p d f}$

Fahruddin (2010). Bioteknologi Lingkungan. Penerbit Alfabeta, Bandung. ISBN: 978-602-8800-14-3

Fahruddin, F., Nur, H., As'adi, A., Abdul, W. \& Rifaat. (2010). Deteksi Unsur Logam Dengan XRF dan Analisis Mikroba pada Limbah Air Asam Tambang dari Pertambangan di Lamuru Kabupaten Bone. Jurnal Geocelebes, 4 (1):7-13. http://journal.unhas.ac.id/index.php/geocelebes/ar $\underline{\text { ticle/view/7831 }}$

Gaikwad, R. W., Sapkal, V. S. \& Sapkal, R. S. (2011). Acid Mine Drainage: A Water Pollution Issue In Mining Industry. International Journal of Advanced Engineering Technology, 2 (4):257-262.

Golar, Muhammad, B., Muhammad, R., Rahmat, B., Bohari, Muhammad, F. P., Muhammad A. \& Laihi, A. (2019). Gold Mining and its Impact on Agricultural Land, Public Health, Violation of the Law: A Study on Poboya Traditional Mining, Palu, Indonesia. Indian Journal of Public Health Research and Development, 10 (10):924. https://www.researchgate.net/publication/338137 138 Gold Mining and its Impact on Agricultu ral Land Public Health Violation of the Law A Study on Poboya_Traditional_Mining_Palu_I ndonesia.
Hasyimuddin, H., Fatmawati, N. \& Indriani, I. (2018). Isolasi Bakteri Pengakumulasi Logam Berat Timbal (Pb) Pada Saluran Pembuangan Limbah Industri Kabupaten Gowa. Biotropic: The Journal of Tropical Biology, 2 (2):126-132. DOI: 10.29080/biotropic.2018.2.2.126-132

Ikerismawati, S. (2019). Bioremediasi Pb Oleh Bakteri Indigen Limbah Cair Agar. Jurnal Biosilampari :Jurnal Biologi, (1) 2: 51-58. DOI: https://doi.org/10.31540/biosilampari.v1i2.288

Jamilah \& Amri (2019) Analisis Bakteri Pengakumulasi Logam Berat Timbal $(\mathrm{Pb})$ di Tanah Pembuangan Limbah Industri Non-Pangan. Celebes Biodiversitas, $\quad 2 \quad$ (2):7-13. http://ojs.stkippi.ac.id/index.php/CB/article/view/ $\underline{172 / 147}$

Jin, Y., Yaning, L., Yangcui, N. \& Lingyan, W. (2018). Review Effects and Mechanisms of Microbial Remediation of Heavy Metals in Soil: A Critical Review. Applied Sciences, 8 (1336): 1- 17. doi: 10.3390/app8081336

Kapahi, M. \& Sarita, S. (2019). Bioremediation Options for Heavy Metal Pollution. Journal Health Pollution. 9 (24): 191203. doi: 10.5696/21569614-9.24.191203

Mu'minah, Baharuddin, B., Subair, H. \& Fahruddin. (2015). Isolation and Screening Bacterial Exopolysaccharide (EPS) From Potato Rhizosphere In Highland And The Potential As A Producer Indole Acetic Acid (IAA). Procedia Food Science (3): 74-81. https://www.researchgate.net/publication/282832 227 Isolation_and_Screening_Bacterial_Exopoly saccharide_EPS from Potato_Rhizosphere in_H ighland and the Potential_as_a_Producer_Indol e_Acetic Acid_IAA

Nur, F. (2013). Fitoremediasi Logam Berat Kadmium (Cd). Biogenesis, 1 (1):74-83. http://journal.uinalauddin.ac.id/index.php/biogenesis/article/viewF $\underline{\text { ile/450/427 }}$

Nurhayati, D. \& Didha, A. P. (2019). Bioakumulasi Logam Berat Pada Kerang Hijau (Perna viridis) di Perairan Cirebon Beradasarkan Musim yang Berbeda. Jurnal Akuatika Indonesia, 4 (1): 6-10. DOI:10.24198/jaki.v4i1.23484.

Palar, H. (2004). Pencemaran dan Toksikologi Logam Berat. Penerbit Rineka Cipta, Jakarta. ISBN: 9795185950 . 
Rinasari E, O., Maulana, Y. \& Taufik, A. (2019). Kajian Pengelolaan Limbah B3 Hasil dari Kegiatan Pertambangan Batubara. Jurnal Pertambangan, 3 (4):52-58.

https://ejournal.unsri.ac.id/index.php/mining/artic $\underline{\text { le/view/10013 }}$

Wawo, R.H.A., Sri, W., Nurliah, J. \& Firman, N. Y. (2017). Analisis Pengaruh Penambangan Emas Terhadap Kondisi Tanah pada Pertambangan
Rakyat Poboya Palu, Provinsi Sulawesi Tengah.

Jurnal Geomine, 5 (3): 116-119. https://jurnal.teknologiindustriumi.ac.id/index.ph $\mathrm{p} / \mathrm{JG} /$ article/view/141

Widyati E. (2007). The Use of Sulphate-Reducing Bacteria In Bioremediation of Ex-Coal Mining $\begin{array}{llll}\text { Soil. } \quad \text { Biodiversitas, } 8 & \text { (4):283-286. }\end{array}$ https://smujo.id/biodiv/article/view/427 